\title{
JUURNAL.RU
}

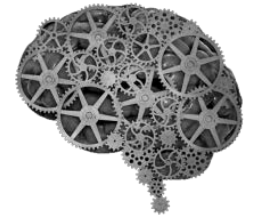

COMPANY GROUP "INTELLEKT"

Ромашкин Т.B. Национальный исследовательский Саратовский государственный университет ил. Н.Г. Чернышевского Саратов, Россия

doi: 10.18411/lj2016-9-3-10

idsp 000001: lj2016-18-3-10

\section{Актуальность создания и развития образовательного кластера в Саратовской области}

В настоящее время современное общество формирует спрос на высокое качество высшего профессионального образования. Однако его состояние весьма противоречиво. Совершенствование системы российского образования набирает обороты. Считаем, что создание образовательных кластеров может быть эффективной формой взаимодействия регионального рынка труда и рынка образовательных услуг [1, С. 158-162].

Кластерный подход - это партнерство, это когерентность институтов, это взаимное развитие и саморазвитие субъектов образовательного кластера.

Образовательный кластер - это институциональная цепочка взаимосвязи науки, бизнеса и технологий, где университет выступает эпицентром инновационного развития в регионе.

Применение кластерного подхода к системе профессионального образования на территории Саратовской области может способствовать кардинальному решению проблем, связанных с трудоустройством выпускников, а также позволит решить ряд задач в рамках стратегической цели - обеспечения отраслей экономики квалифицированными кадрами:

1) необходима система квалификационных требований для использования системы профессионального образования;

2) создание и развитие механизма взаимодействия системы профессионального образования и предприятий региона;

3) проведение регулярного мониторинга предприятий, отраслей, вузов; 
4) анализ показателей развития региона с целью выявления потребности в специалистах по отраслям экономики;

5) оказание предприятиям консалтинговых услуг по подбору специалистов, вузам - по формированию структуры выпускаемых специальностей.

Организация регионального образовательного кластера предлагается через интеграцию взаимосвязанных элементов, где в качестве эпицентра выступают вузы, вспомогательными элементами являются предприятия различных отраслей и секторов экономики региона, организации некоммерческого сектора экономики, региональные органы власти, слушатели образовательных программ - студенты, выпускники, молодые специалисты [2, С. 25-27]. Именно через партнерскую взаимосвязь вузов с остальными субъектами образовательного кластера, без снижения значимости фундаментального знания, с повышением качества развития практических навыков усилится подготовка студентов вуза к современным требованиям рынка труда, появится возможность открытия перспективных специальностей, введения новых дисциплин и современных технологий обучения. Автор считает необходимым построение особой модели тесного взаимодействия вузов Саратовского региона с другими участниками кластера, особенностью которого является принцип единства содержательного, процессуального и результативного аспектов реализации партнерских отношений в системе профессионального образования.

Учитывая, что высокая доля трудоустроенных выпускников свидетельствует о качестве предоставляемых образовательных услуг, вуз, являясь ядром образовательного кластера, принимает активное участие в обеспечении занятости выпускников посредством деятельности центров содействия трудоустройству, презентации компаний, адаптацию выпускников к условиям рынка труда, обучение способам самопрезентации на собеседовании и т.п. Выпускники, студенты, молодые специалисты являются неотъемлемыми участниками образовательного кластера, в рамках которого получают возможность быть вовлеченными в сферу будущей профессиональной деятельности, изучать, обобщать и накапливать передовой опыт, апробировать достижения науки. 
Региональные органы власти выполняют регуляционную функцию, формируют приоритеты регионального развития, осуществляют мониторинг регионального рынка труда, обеспечивают нормативно-правовое регулирование деятельности образовательного кластера. Вуз взаимодействует на рынке труда с организациями негосударственного сектора: кадровыми и рекрутинговыми агентствами, общественными некоммерческими организациями, фондами, которые информируют о вакансиях на рынке труда, о возможностях стажировок и переобучении, оказывают содействие выпускникам в поиске работы, помощь в организации собственного дела, оказывают консультативные психологические и юридические услуги.

Необходимо повышать привлекательность взаимодействия между местными учебными заведениями профессионального образования и предприятиями отрасли. Для работодателя-заказчика образовательных услуг образовательный кластер является фабрикой комплексного практикоориентированного знания, позволяющего определить зоны приоритетных инвестиционных вложений $[3$, с. 102]. Считаем, что для подготовки конкурентоспособных специалистов, нужна согласованность, учебных планов, рабочих образовательных программ и компетенций выпускников, с работодателями.

Представляется, что для создания образовательного кластера на территории Саратовской области необходимы: разработка методических рекомендаций по процессу создания кластеров; осуществление подготовки всех участников кластера; определение высших учебных заведений, способных выступить эпицентром кластеров; разработка и реализация программы поддержки кластерных инициатив в регионе, в том числе инвестиционное, информационное, кадровое, энергетическое обеспечение развития кластеров; проведение мониторинга и оценка эффективности применения кластерной политики.

Правомерен вывод о том, что совершенствование сотрудничества университетов региона с участниками образовательного кластера может существенно повлиять на востребованность кадров на рынке труда, тем самым оказать положительное воздействие на увеличение занятости населения. Основной задачей деятельности образовательного кластера на данном этапе 
развития Саратовской области должно быть сокращение разрыва между потребностями регионального рынка труда и предложением рынка образовательных услуг, что приведет к более эффективному взаимодействию этих двух рынков и социально-экономическому развитию региона.

\section{Литература:}

1. Ромашкин Т.В. Модернизация системы образования - вектор инновационного развития России. //Проблемы и перспективы развития науки в России и мире. Сборник статей Международной научнопрактической конференции. 2016. С. 158-162.

2. Устинова Н.Г. Виртуализация инновационной инфраструктуры. В книге: научная мысль и современный опыт в решении системных проблем развития. Сборник научных трудов по итогам научно-исследовательской работы ученых Саратовского социально-экономического института (филиала) ФГБОУ ВПО «РЭУ им. Г.В. Плеханова» по итогам 2013 г. 2014. C. 25-27.

3. Смирнов А.В. Образовательные кластеры и инновационное обучение в вузе. Казань, 2010. С. 102. 